\title{
Winter release and management of reintroduced migratory Whooping Cranes Grus americana
}

\author{
RICHARD P. URBANEK, LARA E. A. FONDOW, SARA E. ZIMORSKI, \\ MARIANNE A. WELLINGTON and MARK A. NIPPER
}

\section{Summary}

From 2001 to 2005, 71 costume-reared juvenile Whooping Cranes Grus americana were led by ultralight aircraft from Wisconsin to a winter release site on the west-central Gulf Coast of Florida. A strategy was developed and implemented to maximize first winter survival while preventing exposure to non-costumed humans and tame Sandhill Cranes, maximize social bonding between males and females, promote safe roosting and wild behaviour, and minimize harassment by Whooping Cranes from earlier releases. Methods were improved each year; these modifications included enlargement of an open-topped release pen, creation of an artificial roosting substrate, addition of a top-netted pen, and holding birds at a distant pen site until older birds had cleared the release area. These techniques resulted in high survival and successful adaptation to the wild after migration from the winter release site.

\section{Introduction}

Of the 15 species of cranes (Gruidae) currently in existence, nine are listed as threatened (IUCN 2008). Although the population of Mississippi Sandhill Cranes Grus canadensis pulla has increased through reintroduction (Ellis et al. 200o), attempts to create new populations of cranes by reintroduction have been limited, and to date none have been successful (Ellis et al. 1992, Folk et al. 2008). The Whooping Crane Grus americana is the rarest species and barely avoided extinction. By the winter of $1941 / 42$, the Whooping Crane was reduced to 21 individuals in two remnant populations: six in a non-migratory population at White Lake, Louisiana, and 15 in a migratory population breeding in Wood Buffalo National Park, Northwest Territories of Canada, and wintering on Aransas National Wildlife Refuge (NWR) on the Texas Gulf Coast. Only the latter population survived and by spring 2007 had increased to 236 individuals (T. Stehn, U.S. Fish and Wildlife Service, unpubl. data).

Recovery efforts, including plans for creation of additional populations, began in the 1960s. In 1966 a captive propagation programme began at Patuxent Wildlife Research Center (Patuxent) in Laurel, Maryland. Eggs were collected from Wood Buffalo National Park. All Whooping Cranes alive today are descendants of the remnant population present at Aransas in 1942.

The first attempted reintroduction of a migratory population began at Grays Lake National Wildlife Refuge, Idaho, in 1975. This was to be a migratory flock wintering in New Mexico. Crossfostering, i.e., placing Whooping Crane eggs in Sandhill Crane (G. canadensis) nests and allowing the foster parents to rear the young, was the primary technique. However, by 1988 poor survival and lack of pair formation proved this technique ineffective, and that effort was eventually discontinued (Ellis et al. 1992).

New techniques were developed and tested with Sandhill Cranes (Horwich 1989, 2001; Ellis et al. 1992; Urbanek and Bookhout 1992, 1994; Nagendran et al. 1996; Lishman et al. 1997; Ellis et al. 2000, 2001a, 2001b, 2003; Duff et al. 2001; Urbanek et al. 2005a) and formed the basis of 
a reintroduction began in Wisconsin in 2001. Costume-reared birds derived from eggs produced in captivity were trained to follow ultralight aircraft and led behind ultralight aircraft from Necedah NWR, Central Wisconsin, to Chassahowitzka NWR on the Central Gulf Coast of Florida (Urbanek et al. 2005b). Initially, a gentle release into winter habitat was planned. However, new challenges arose on the wintering grounds, and a new strategy and new techniques were needed to promote survival and subsequent behaviours necessary to make establishment of a population possible. This paper documents the management of juvenile Whooping Cranes on the winter release site and how that management evolved to achieve these goals.

This paper is a contribution of the Whooping Crane Eastern Partnership (WCEP), a consortium of federal and state agencies and non-profit organisations committed to reestablishment of a migratory population of Whooping Cranes in eastern North America.

\section{Methods}

\section{Study areas}

The core reintroduction area in central Wisconsin consists of a large shallow wetland complex in Juneau, Wood, Jackson, Monroe, Clark, and Adams Counties, Wisconsin. The landscape is an interspersion of shallow wetlands, forests, and farmlands on poorly drained, sandy soils with low topographic relief. Approximately 20,170 ha of marsh is on federal or state land, and at least as much shallow wetland occurs on other lands, including cranberry properties, within this core area. Wetlands are dominated by sedges (Carex spp.) and willows (Salix spp.). The specific site of the reintroduction, Necedah NWR $\left(44^{\circ} \mathrm{O}^{\prime} \mathrm{N}, 90^{\circ} \mathrm{IO} \mathrm{O}^{\prime} \mathrm{W}\right)$, contains approximately 7,725 ha of suitable crane habitat in marshland (6,86o ha) or managed pools (865 ha).

The reintroduced Whooping Cranes migrate along the same route used by the wild Sandhill Crane population (Toepfer and Crete 1979, McMillen 1988, Urbanek 1988). This route extends from Central Wisconsin through Indiana and Tennessee to the southeastern U.S.A.

A saltwater winter release site had been selected to: (I) approximate saltwater habitat used by wintering Whooping Cranes in the natural population at Aransas NWR, Texas, and (2) avoid possible conflicts with a reintroduction of non-migratory Whooping Cranes ongoing since 1993 in inland peninsular Florida. The release site, Chassahowitzka NWR $\left(28^{\circ} 44^{\prime} \mathrm{N}, 82^{\circ} 39^{\prime} \mathrm{W}\right)$, Citrus County, Florida, was located in an area representative of the surrounding salt marsh. Typical salt/brackish marsh habitats characteristic of the Central Gulf Coast were located within $2.4 \mathrm{~km}$ of the pen. Dominant vegetation consists of extensive monotypic stands of Black Needlerush Juncus roemerianus with scattered islands of Cabbage Palm Sabal palmetto. Surface access was possible only by airboat and was permitted to project staff; airboat operation by the public on this part of the refuge was prohibited.

A temporary holding site was added in winter $2005 / 06$ on Halpata Tastanaki Preserve $\left(29^{\circ} \mathrm{O} 2^{\prime} \mathrm{N}\right.$, $82^{\circ} 25^{\prime} \mathrm{W}$ ), Southwest Florida Water Management District, Marion County. This was an inland freshwater site $42 \mathrm{~km}$ northeast of the winter release site on Chassahowitzka NWR and was used to hold the juveniles until older Whooping Cranes had cleared the latter site.

\section{Reintroduction methods}

Whooping Cranes were hatched ( 12 April-5 June) at Patuxent from eggs produced there, at the International Crane Foundation, Calgary Zoo, and other facilities with captive pairs. Chicks were costume-reared (Horwich 1989, Urbanek and Bookhout 1992, Ellis et al. 2000) and then trained from shortly after hatching to follow ultralight trike aircraft (Cosmos, Dijon, France) according to techniques developed by Operation Migration, Blackstock, Ontario (Lishman et al. 1997, Duff et al. 2001). At Patuxent chicks were led on foraging trips by costumed caretakers, led by ultralight aircraft around a circular pen (chicks inside the fence and the aircraft outside), and led 
by ultralight aircraft in an open field with chicks on one side of a $0.5 \mathrm{~m}$-high vinyl-coated wire fence and the aircraft on the other (Figure 1). At 35-65 days of age ( 12 June-15 July), chicks were transferred to large, top-netted outdoor pens with adjacent aircraft training areas on Necedah NWR, Wisconsin. There training to follow aircraft continued until migration (G. Olsen, Patuxent Wildlife Research Center, and J. Duff, Operation Migration, unpubl. data).

Each year the three (two in 2001) juvenile cohorts were combined into a single flock by midAugust to mid-September. These flocks began migration from Necedah NWR 10-17 October. They arrived on the release site (Chassahowitzka NWR, 2001-04) or the holding site (Halpata Tastanaki Preserve, 2005) 30 November-13 December. Because of the rearing method, cranes could be controlled and retrieved after release by costumed staff as necessary, thus greatly facilitating many options for their subsequent management.

A small top-netted holding pen was erected within the larger pen on Chassahowitzka NWR in winters 2001/02 to 2003/04 to temporarily hold birds for a few days before release into the large open-topped pen. The brief holding period facilitated handling for health examinations and/or banding and provided initial acclimatisation of the cranes to the new, unfamiliar environment under controlled conditions. The latter pen was expanded from 0.6 ha in winter 2001/02 to 1.6 ha in winter 2002/03 to provide improved roosting conditions and space for more birds. The expanded portions included ( $I$ ) a deeper pool and (2) an artificially constructed oyster bar ( $17 \mathrm{~m}$ long $\times$ $9 \mathrm{~m}$ wide at the center and on top of an existing natural oyster bar). Also included was an area of Salt Grass Distichlis spicata, originally just outside the southeast boundary of the old pen, that had been a favourite loafing area for the HY (hatch-year) 2001 birds during their first winter and on which they frequently attempted to roost. With these improvements, water of suitable roosting depth was present somewhere in the pen at most tidal levels during and after winter 2002/03.

Areas burned by prescription were also present, adjacent to and in the vicinity of the pen. These amounted to several hundred hectares in winter 2001/02 but were less extensive in winter 2002/03. These burns constituted most of the area outside of the pen that was usable by the cranes until early March. By that time needlerush had regrown and rendered much of the burned areas again unusable. In subsequent winters the needlerush was mechanically mashed by a belttrack amphibious vehicle. This process kept the area near the pen open and usable by cranes by killing the needlerush. These areas eventually succeeded to Salt Grass.

In winter 2004/05 a permanent $(12 \times 20-\mathrm{m}$ oval $)$ top-netted pen was erected on the southwestern corner of the main pen. This pen was used to hold juveniles while older returning birds were using the site and during periods of unavailability of trained staff.

In winter 2005/06 a holding site at Halpata Tastanaki Preserve was used to hold the juveniles until after most returning, older birds had cleared the release site on Chassahowitzka NWR. Birds

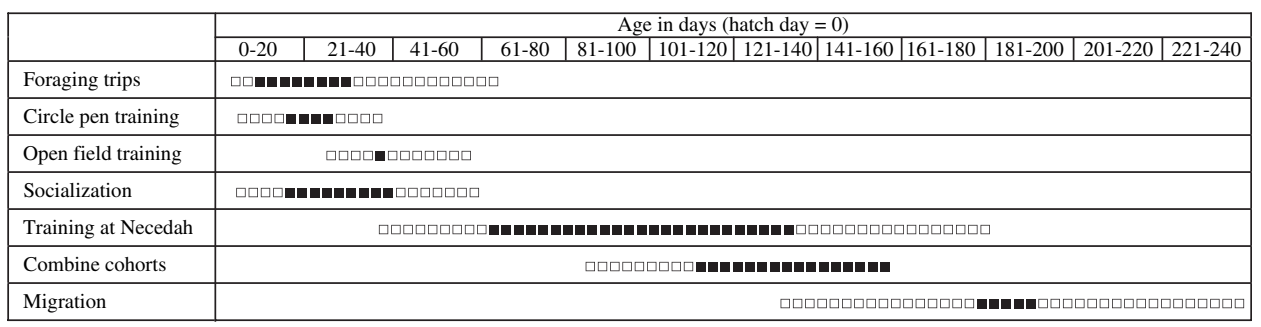

- All birds of this age involved.

$\square$ Some birds of this age involved.

Figure 1. Training and migration timeline for ultralight-led juveniles of the eastern migratory Whooping Crane reintroduction. Procedures 1-4 occurred at Patuxent Wildlife Research Center and 5-6 at Necedah National Wildlife Refuge. 
were kept in a o.o6-ha circular, top-netted pen during the night and when not under caretaker supervision. They were provided exercise outside of the top-netted pen. The juveniles were then led by ultralight aircraft to the release site in early January.

Released cranes were provided with commercial pellet feed ad libitum in feeders in all pens during each winter.

All juveniles were individually marked with coloured leg bands and equipped with legbandmounted VHF (164-166 MHz) lithium battery transmitters (Advanced Telemetry Systems, Isanti, $\mathrm{MN}$ ) before release. Legband-mounted PTTs (platform transmitter terminals, Microwave Telemetry, Columbia, MD), i.e., satellite-monitored radios, were also attached to approximately three juveniles per year. Cranes were tracked by conventional (VHF) telemetry with scanner receivers (Advanced Telemetry Systems, Isanti, MN; Telonics, Mesa, AZ). Most of this tracking was done from vehicles on the ground, although Cessna aircraft were sometimes used, especially during migration and to search for temporarily missing birds. Each ground tracking vehicle was equipped with a through-the-roof, 7-element yagi antenna (Cushcraft Corporation, Manchester, NH).

A dedicated team of 3-4 trackers continuously monitored released cranes by VHF radio-telemetry throughout the annual cycle and geographic range of the cranes. Resources were apportioned to cover as many birds as possible with priorities assigned to youngest birds or those with most variable movement patterns. Coordinates of locations were recorded, and where access permitted, visual observations were made to document habitat and associations among Whooping Cranes and with Sandhill Cranes. PTTs were used to identify distant search locations in areas not routinely covered by VHF tracking, and follow up VHF tracking was performed at these sites as possible. PTTs were programmed to transmit more frequently during youngest age periods and migrations; the transmission cycle covered two consecutive roost nights each to days during the yearling, i.e., first unassisted, winter. On the wintering grounds monitoring effort was determined by logistics of travel with birds within $100 \mathrm{~km}$ of Chassahowitzka NWR being checked at least twice per week. Other cranes were checked less frequently as resources permitted, and cooperators were often recruited and used to check birds outside Florida. The monitoring programme was very effective, missing only a few birds during all or part of any winter, and all released cranes, alive or dead, were accounted for through most and at the end of the study period. Reported survival is actual and is not an estimate.

\section{Results}

\section{Roosting behaviour-winter 1}

The first group of reintroduced juveniles was released during the 2001/02 winter and was small, i.e., five, during most of the winter. They occupied the original o.6-ha release pen. This small pen did not provide water of suitable roosting depth under all tidal conditions, nor a preferred firm and smooth roosting substrate. Water suitable for roosting includes depths that completely cover the toes to those reaching the upper part of the tarsus just below the hock or $3-23 \mathrm{~cm}$.

Within the pen, water level measured at dusk, 18 January-8 April 2002 ( $n=81$ nights), was of suitable roosting depth in the tidal pool on $31 \%$ of nights. On $5 \%$ of nights the pool was exposed mudflat. On $11 \%$ of nights, tidal creeks and pools exceeded their banks and flooded the entire landscape, providing suitable roosting habitat. However, on $53 \%$ of nights water remained within the banks of the tidal creeks and pools but was too deep for roosting. This situation often resulted in cranes roosting on land, which was undesirable because this reinforces improper roosting behaviour that could increase susceptibility to predation after release.

The cranes frequently flew out of the pen at roosting time and landed on the adjacent Salt Grass plain. This area was usually unsuitable for roosting because water was too shallow to provide protection from predatory Bobcats Lynx rufus. Juveniles then had to be led back into the pen by a costumed caretaker at dusk on $37 \%$ of nights. Birds did roost safely outside the pen on $17 \%$ of nights, either during extremely low tides, when birds usually roosted in a tidal pool east 
of the pen, or extremely high tides, when birds were allowed to roost on the flooded Salt Grass loafing area adjacent to the pen. Cranes went to roost in water a safe distance from shore, either within or outside the pen, on $34 \%$ of nights. Otherwise, they roosted on land within the pen.

\section{Roosting behaviour-winter 2}

There were 16 juveniles in the group released during winter 2002/03. One yearling also returned and remained to winter at the release site. Roosting conditions and subsequent roosting behaviour greatly improved in comparison to the previous winter after enlargement of the pen and construction of the artificial oyster bar. During 30 November-31 March, cranes only needed to be led into the pen on eight nights and then only 1-7 individuals. During this winter, cranes strongly preferred to roost on the smooth, firm surface of the constructed oyster bar or the immediately adjacent shoreline.

During winter 2002/03, cranes initiated roosting outside the pen on only eight nights, and all of the cranes on only three of those nights. Two of these nights occurred while water levels were high in late March, and birds roosted on the flooded plain adjacent to the west pen boundary. Otherwise, roosting outside the pen occurred during low tides in a 40-50 m wide portion of a tidal creek south of the pen.

\section{Salinity}

Whooping Cranes will drink water with salinity less than 23 parts per thousand (ppt) (Allen 1952, Hunt 1987). Salinities near the pen site were generally too high to provide a good source of drinking water: January (19-21), February (17-24), March (19-23), April (23-25). Salinity usually decreased briefly only after heavy rains. Cranes were largely dependent on fresh water artificially provided in a drinking receptacle.

\section{Predation}

Seven juvenile Whooping Cranes were released into the open-topped pen on Chassahowitzka NWR on 6-7 December 2001. By 9 January, two birds had been killed by Bobcats while outside the pen. The offending Bobcats were trapped and removed from the area, and a continuous trapping effort was implemented. Although Bobcat sign occasionally reappeared near the pen site, no additional Bobcats were captured. After the second mortality, more rigorous overnight protection measures were implemented. These included ensuring that the birds roosted either within the predator-proofed pen or, if outside, in safe roosting habitat, i.e., in water more than $6 \mathrm{~m}$ from shore.

No additional mortalities occurred at the release site until March 2005. At that time the juveniles developed a habit of leaving the pen just before dark to roost outside, in or along a tidal creek that provided safe roosting habitat only at low or extremely high tides. During that winter, the area between the pen and the tidal creek was covered with rank growth of needlerush through which the juveniles could not be led back to the pen by costumed caretakers. After a juvenile was killed by a Bobcat while attempting to roost along the tidal creek, an airboat was successfully used to flush cranes from that area back to the pen when they continued to attempt to roost there. Before the next winter, the access problem was solved by mashing the needlerush between the pen and the tidal creek with an amphibious belt-track vehicle prior to arrival of the birds. Other techniques used successfully to promote survival included use of a caretaker covered with a stiff vinyl tarpaulin, i.e., "swamp monster", to flush birds from unsafe roosting areas and a loudspeaker broadcasting brood or contact calls with which the juveniles were accustomed to call birds back to the pen. No additional birds were lost to predation after these additional measures were implemented. 


\section{Harassment by older returning cranes}

Cranes from releases in previous winters normally returned to the release site, remained a short period, and then moved to preferred habitat inland. However, once the current year juveniles completed ultralight aircraft-led migration to the winter release site, their presence was an attractant to the older cranes, which tended to remain to harass the juveniles. This harassment consisted of dominance of feeding stations and chasing juveniles, most critically out of the protection of the predator-proofed pen at roost time. As the population grew, these problems increased, especially when completion of migration by the returning older birds overlapped with arrival of the juveniles.

During 2004 the autumn migration of older cranes was protracted and late. Migration of individual birds or groups to the Central Gulf Coast was completed in $5-58$ days with arrival of the last birds on 2 January 2005. The earliest returning crane arrived on approximately 15 November and moved inland on 25 November. A pair arrived at the Chassahowitzka pen site on the latter date and moved inland on 28 November. The next cranes to return to the pen site, a subadult triad, did not arrive until 15 December. A total of 13 older cranes in six groups stopped over at the pen site during early winter. Other than one pair, the last of these cranes left the pen site on 3 February to spend the remainder of the winter inland. The exception was a pair (HY2OOI male and HY2002 female) that maintained a winter territory that included the pen site area.

The HY2004 ultralight-led juveniles consisted of 13 released birds and arrived at the winter release pen on Chassahowitzka NWR on 12 December. All arrivals of the older returning birds occurred after arrival of the ultralight-led group except for the earliest arriving female, which left the site on 25 November and did not return until 29 January, and the local territorial pair, which had an alternate local winter site and frequently returned. Presence of the juveniles at the Chassahowitzka pen site resulted in protracted stay of older birds at the site. The most serious problem with harassment by older birds involved the subadult triad, which was present at the pen most of the time from 15 December to 3 February.

To prevent harassment by the older cranes during this winter, the juveniles were frequently held in the top-netted enclosure that had been constructed on a corner of the main pen (Table I). In previous years, a top-netted enclosure had only been used to hold the birds for a brief acclimatisation period after arrival at the Chassahowitzka pen. Juveniles were permitted out of

Table 1 . Subsequent mortality and homing of Whooping Cranes led as juveniles by ultralight aircraft to Chassahowitzka National Wildlife Refuge, Citrus County, Florida.

\begin{tabular}{|c|c|c|c|c|c|}
\hline & HY2001 & $\mathrm{HY}_{2002}$ & $\mathrm{HY}_{2003}$ & $\mathrm{HY}_{2004}$ & $\mathrm{HY}_{2005}$ \\
\hline No. birds released & 7 & 16 & 16 & 13 & 19 \\
\hline Mean no. days in top-netted pen & o & o & o & $61^{\mathrm{a}}$ & 10 \\
\hline Mean no. days free & 125 & 122 & 111 & $42^{b}$ & 56 \\
\hline \multicolumn{6}{|l|}{ Mortality: } \\
\hline First Winter & 2 & $\mathrm{o}$ & $\mathrm{o}$ & 1 & o \\
\hline Spring Migration & o & o & $\mathrm{o}$ & $\mathrm{o}$ & o \\
\hline Spring & $\mathrm{o}$ & o & o & 1 & o \\
\hline Summer & $\mathrm{o}$ & $0^{c}$ & $I^{d}$ & o & $I^{\mathrm{d}}$ \\
\hline Autumn Staging & o & o & o & $\mathrm{o}$ & o \\
\hline Autumn Migration & $\mathrm{o}$ & o & 1 & $\mathrm{o}$ & o \\
\hline Second Winter & $\mathrm{o}$ & o & o & $\mathrm{o}$ & 2 \\
\hline \multicolumn{6}{|l|}{ Homing in Second Winter: } \\
\hline Return to WC/NC peninsular Florida & $5 / 5$ & $14 / 15$ & $3 / 14$ & $11 / 11$ & $17 / 18$ \\
\hline
\end{tabular}

${ }^{\mathrm{a}} 47$ and 14 days, respectively, in top-netted enclosure before and after final departure of group of 3 dominant HY20O2 subadults.

$\mathrm{b}_{7}$ and 35 days free, respectively, before and after final departure of group of 3 dominant HY20O2 subadults.

$c_{1}$ female died from a non-environmental factor (capture myopathy) during the summer.

${ }^{\mathrm{d} I n}$ Michigan. 
the enclosure only when costumed caretakers were present or when no older, dominant cranes were present (some exceptions for the resident wintering pair). Older birds were also not given free access to supplied feed and fresh water. This regimen was continued until 2 March, after which no older cranes other than the resident pair appeared at the pen site, and the juveniles were allowed to roam freely.

\section{Holding site on Halpata Tastanaki Preserve}

During the fifth winter of the reintroduction, the site at Halpata Tastanaki Preserve was selected to hold the juveniles until the older birds had passed through Chassahowitzka and moved inland. Use of this temporary holding site alleviated the problem of retention of older birds and resulting interference with management of the juvenile flock at the Chassahowitzka pen site. The 19 ultralight-led juveniles arrived at the holding site on 13 December 2005.

The final migrating adults cleared the Chassahowitzka pen site on 25 December 2005. Eighteen of 19 ultralight-juveniles were led to the pen by ultralight aircraft on 9-11 January. One juvenile was transported there by boat on 19 January. After a brief acclimatisation period, all 19 juveniles were released from the top-netted enclosure on 21 January. A submissive $\mathrm{HY}_{2003}$ female also wintered with the juveniles at the site. Use of the holding site at Halpata resulted in a $44 \%$ decrease in use of the top-netted enclosure at the Chassahowitzka pen site compared to the previous winter (Table 1 ).

\section{Survival and behaviour after the juvenile winter}

Mean survival of the released birds during the first year after leaving the protective care provided during the first winter was $87 \%$. These Whooping Cranes used appropriate habitat in subsequent winters (Fondow 2008). There was no significant difference (chi-square test with continuity adjustment, $\left.\chi_{1}^{2}=0.076, P=0.782\right)$ in mortality from release through the second winter for birds held $(5 / 32)$ or not held $(4 / 38)$ in a top-netted pen during the first winter (Table 1 ). There was significantly greater homing to northwestern and west-central peninsular Florida during the second winter for birds held (28/29) versus not held (22/34) in a top-netted pen during their first winter $\left(\chi_{1}^{2}=9.69, P=0.0018\right)$. However, this difference was due largely to the movements of 10 birds in the HY2003 cohort to the Carolinas. Excluding the latter cohort, winter homing was similar for birds held (28/29) or not held (19/20) in a top-netted pen during the first winter.

\section{Population distribution}

Release of juveniles at Chassahowitzka NWR resulted in occurrence of $47.5 \%$ of returning birdwinters in a primary wintering area within $0-88 \mathrm{~km}$ of the release site and an additional $12.0 \%$ 82-103 km northward near Paynes Prairie (Figure 2). Some birds wintered at a frequently used migration stopover area in or near Hixtown Swamp and San Pedro Bay 172-217 km north of the release site (9.7\%), and $10.7 \%$ short-stopped yet farther north in Alabama, Tennessee, or southern Indiana. A small concentration of birds, all $\mathrm{HY}_{2} \mathrm{OO} 3$ or their associates, wintered consistently in the Ace Basin region of South Carolina (7.4\%), and $4.0 \%$ occurred at other locations in the Carolinas. A total of $8.0 \%$ of bird-winters occurred at scattered locations in Florida or southern Georgia outside of the areas noted above, and a single bird overwintered once in southeastern Louisiana.

\section{Discussion}

\section{Problems and solutions during the first winter of the reintroduction}

The primary goal shifted from acclimatisation and release of juvenile Whooping Cranes into natural habitats of Florida to caring for and managing the juveniles to keep them alive during 


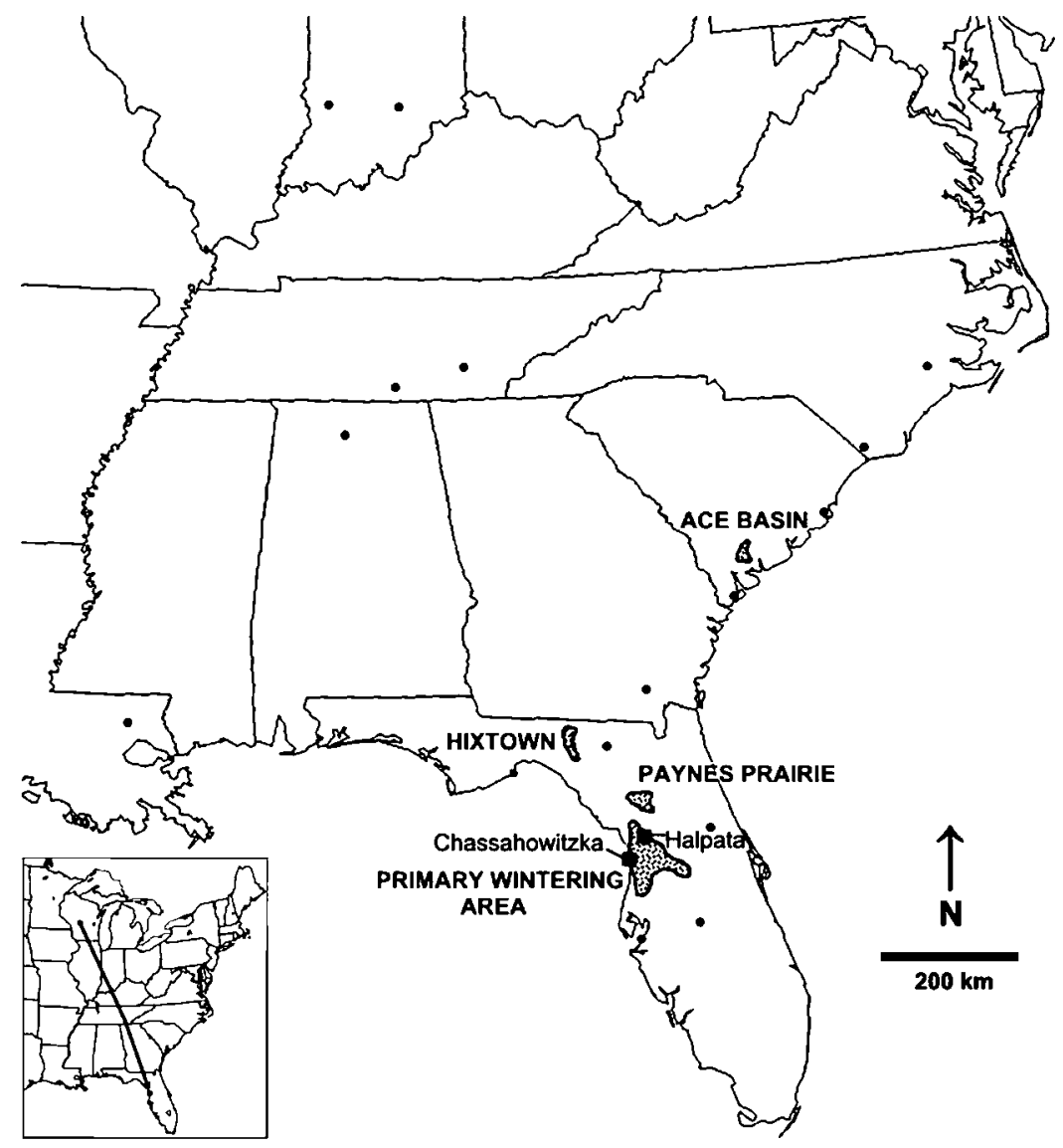

Figure 2. Distribution of reintroduced migratory Whooping Cranes in southeastern U.S.A. during winters 2002/03-2006/07. Concentrations of wintering sites are stippled. Dots indicate disparate wintering sites of 1-3 cranes. Hixtown includes San Pedro Bay. All bird locations were known except for two during single winters and four during single half-winters. Location of an additional bird that was held in captivity and released during the latter half of one winter was also not included.

their first winter. The change in strategy was a result of ( 1 ) confirmation of predation by Bobcats as a critical mortality factor and (2) lack of suitability of the saltmarsh at the release site as habitat for the future wintering population. Predation of Whooping Cranes by Bobcats had already been identified as a serious problem in the attempted reintroduction of a non-migratory flock inland in Florida (Nesbitt et al. 1997, 2001). The new strategy allowed the released birds to fully adapt to the wild after migrating from Florida to areas where risk of predation and habitat conditions were more conducive to survival and learning by naive, captive-reared birds.

\section{Survival and management strategy to avoid predation}

Survival early in reintroduction of the eastern migratory population has significantly exceeded results of earlier reintroduction attempts (Drewien et al. 1989, Nesbitt et al. 1997, 2001). The management strategy of protecting the released birds during their first winter at Chassahowitzka 
NWR was effective. When employed, this strategy resulted in $100 \%$ survival of naive, newly released birds while they occupied areas with high Bobcat densities. Once birds leave on spring migration, they are not subject to high densities of this predator (Anderson and Lovallo 2003; R. Urbanek, U.S. Fish and Wildlife Service, pers. obs.). By their return to Florida the following winter, they were more predator-wary and adept at selection of safe habitat. Association with Sandhill Cranes on the summering areas likely facilitated this process.

\section{Habitat of the release site}

Although the winter release site was saltmarsh, lack of protection from a barrier island and resulting greater tidal fluctuation than at Aransas NWR precluded suitability of Chassahowitzka NWR as a future wintering area for significant numbers of Whooping Cranes. Although addition of the constructed oyster bar with its variation in topography increased water depths usable for roosting, tidal variation during the night made roosting difficult. Lunar tide charts indicate changes of $10-56 \mathrm{~cm}$ overnight $($ mean $=30 \mathrm{~cm}$ ) during winter. In addition, wind was a dominant and unpredictable factor affecting tides on the shallow Gulf Coast. Lack of fresh water for drinking, oyster rock and soft muck substrates, and dense vegetation dominated by Black Needlerush also diminished habitat quality on Chassahowitzka NWR.

However, occupation of the release site on Chassahowitzka NWR during the first winter had no adverse effect on selection of habitat by cranes in their subsequent winters. Most of the Whooping Cranes returned to the salt marsh after the second southward migration and then left shortly thereafter to inhabit nearby areas inland. The most preferred habitat appeared to be large cattle ranches containing extensive, large, shallow ponds (Nesbitt et al. 1997, Fondow 2008).

Use of a release site for juveniles that was separate from the wintering area of older birds has been advantageous by allowing use of the same isolated, well-constructed, and protective pen site for multiple years. Cranes overwintering at the pen site could be successfully protected from predators and effectively isolated from human activity, the latter of which could compromise their wildness during the critical period just after release. This winter release strategy reduced the problem of dominant older birds interfering with the feeding by the juveniles and driving them into unprotected roosting habitat or areas near human activity. These advantages would not have been possible with an inland freshwater site. Effects of drought, a significant and growing problem in wetlands of inland Florida, were also avoided by use of a coastal site.

Because of its unique features, Chassahowitzka NWR provided an effective release site on which to implement a protective strategy. Major threats to success of reintroduction of captive-reared cranes are predation and failure to remain in appropriate habitats and avoid areas occupied by humans. Adverse effects are most damaging to naive, newly released juveniles. Taming may occur as a result of exposure to humans and human activities. Taming is also facilitated by association with tame non-migratory Sandhill Cranes. The Chassahowitzka site was well-protected with no physical public access and contained no Sandhill Cranes. The site also had well-constructed facilities, and a management protocol was developed that was successful in reducing or eliminating predation. The pen area was frequently cleaned by tidal flushing with salt water, an advantage not present at inland sites. Addition of a pen site at Halpata Tastanaki Preserve to hold juveniles until older returning Whooping Cranes had cleared the Chassahowitzka pen site and moved inland solved most problems related to aggression and competition for food and space at the pen by the older Whooping Cranes. When older birds were present, temporary retention of juveniles in the top-netted enclosure at the Chassahowitzka pen site was effective. Juveniles demonstrated appropriate, normal behaviour during subsequent migration and summering in Wisconsin.

Selection of Chassahowitzka NWR as a release site resulted in a primary wintering area in west-central Florida with secondary wintering areas along the migration route farther north in the state. Although tides, salinity, and substrate did not contribute to long-term usable habitat by returning, wintering Whooping Cranes, these cranes successfully learned to overwinter in appropriate habitat at inland sites. Because of the fragmented nature of Florida and the lack of large 
blocks of protected habitat suitable for Whooping Cranes (e.g., there is no area similar in contiguity, size, and habitat quality to Aransas NWR), use of a release site that is the same as the ultimate winter reintroduction area is not an option for this population. Historically, no conventional reintroduction techniques have so far resulted in a self-sustaining wild population of a threatened crane species. However, the current reintroduction attempt, with continuing modifications, has so far produced birds with survival and wild adaptation capabilities necessary for this reintroduction to ultimately succeed.

\section{Management implications}

We developed and implemented a winter release strategy which (I) reduced predation of juvenile Whooping Cranes by Bobcats, (2) prevented exposure and habituation of juveniles to human activity and tame non-migratory Sandhill Cranes, (3) ensured that juveniles were functional in the wild after they completed their first winter and began spring migration, (4) minimized harassment of juveniles by older wintering Whooping Cranes, (5) promoted use of appropriate habitats during subsequent winters, and (6) facilitated social structure and association of females with males. The population remains in the initial stages of formation, and additional modifications in technique will continue to be made to make successful establishment possible.

\section{Acknowledgments}

This paper is a product of the Whooping Crane Eastern Partnership, which was established in 1999 to reintroduce a migratory population of Whooping Cranes to eastern North America. The nine founding members are the Canada-U.S. Whooping Crane Recovery Team, U.S. Fish and Wildlife Service, USGS Patuxent Wildlife Research Center, USGS National Wildlife Health Center, Wisconsin Department of Natural Resources, Operation Migration, Inc., International Crane Foundation, National Fish and Wildlife Foundation, and Natural Resources Foundation of Wisconsin. Many additional organizations and individuals have played an important role in the reintroduction, and the efforts of all participants are acknowledged as vital to its success. We thank Patuxent, especially J. French, G. Gee, G. Olsen, D. Sprague, J. Chandler, K. O'Malley, B. and B. Clauss, R. Doyle, and C. Shafer, and Operation Migration, especially J. Duff, D. Clark, R. van Heuvelen, W. Lishman, B. Pennypacker, and C. Gullikson, for chick rearing and ultralight aircraft-led migrations. We thank the International Crane Foundation, especially C. Satyshur, J. Watson, S. Castelda, C. Malachowski, S. Kerley, and T. Love, for tracking released birds. We are grateful to J. Kraus, B. Brooks, L. Wargowsky, and J. Christian, U.S. Fish and Wildlife Service; S. Blitch and N. Robbins, Florida Department of Environmental Protection; and M. Barnwell, Southwest Florida Water Management District; for support and provision of facilities. We thank the many additional cooperators and state personnel who assisted in monitoring. T. Kohler, Windway Capital Corporation, graciously provided tracking aircraft and financial support. S. Swengel, D. Ellis, and P. Seddon made valuable comments on the manuscript.

\section{References}

Allen, R. P. (1952) The whooping crane. New York: National Audubon Society. Research Report 3.

Anderson, E. M. and Lovallo, M. J. (2003) Bobcat and lynx. Pp. $758-786$ in G. A. Feldhamer, B. C. Thompson, and J. A. Chapman, eds. Wild mammals of North America: biology, management, and conservation. Second edition. Baltimore, Maryland: John Hopkins University Press. Drewien, R. C., Brown, W. M. and Bizeau, E. G. (1989) Whooping crane cross-fostering experiment. Moscow, Idaho: Wildlife Research Institute, University of Idaho.

Duff, J. W., Lishman, W. A., Clark, D. A., Gee, G. F. and Ellis, D. H. (2001) Results of 
the first ultralight-led sandhill crane migration in eastern North America. Proc. North Am. Crane Workshop 8: 109-114.

Ellis, D. H., Lewis, J. C., Gee, G. F., and Smith, D. G. (1992) Population recovery of the whooping crane with emphasis on reintroduction efforts: past and future. Proc. North Am. Crane Workshop 6: 142-150.

Ellis, D. H., Gee, G. F., Hereford, S. G., Olsen, G. H., Chisolm, T. D., Nicolich, J. M., Sullivan, K. A., Thomas, N. J., Nagendran, M. and Hatfield, J. S. (200o) Post-release survival of hand-reared and parent-reared Mississippi sandhill cranes. Condor 102: 104-112.

Ellis, D. H., Gee, G. F., Clegg, K. R., Duff, J. W., Lishman, W. A. and Sladen, W. J. L. (2001a) Lessons from motorized migrations. Proc. North Am. Crane Workshop 8: 139-144.

Ellis, D. H., Mummert, D. P., Urbanek, R. P., Kinloch, M., Mellon, C., Dolbeare, T., and Ossi, D. P. (2001b) The one-by-one method for releasing cranes. Proc. North Am. Crane Workshop 8: 225.

Ellis, D. H., Sladen, W. J. L., Lishman, W. A., Clegg, K. R., Duff, J. W., Gee, G. F. and Lewis, J. C. (2003) Motorized migrations: the future or mere fantasy? Bioscience 53: 260-264.

Folk, M. J., Nesbitt, S. A., Parker, J. M., Spalding, M. G., Baynes, S. B., and Candelora, K. L. (2008) Current status of nonmigratory whooping cranes in Florida. Proc. North Am. Crane Workshop 10: 7-12.

Fondow, L. E. A. (2008) Winter habitat selection by a reintroduced population of migratory whooping cranes: emerging patterns and implications for the future. Proc. North Am. Crane Workshop 10: 152.

Horwich, R. H. (1989) Use of surrogate parental models and age periods in a successful release of hand-reared Sandhill Cranes. Zoo Biol. 8: 379-390.

Horwich, R. H. (2001) Developing a migratory whooping crane flock. Proc. North Am. Crane Workshop 8: 85-95.

Hunt, H. E. (1987) The effects of burning and grazing on habitat use by whooping cranes and sandhills cranes on the Aransas $\mathrm{Na}$ tional Wildlife Refuge, Texas. Ph.D. dissertation. College Station, Texas: Texas A\&M University.
IUCN. (2008) 2008 IUCN red list of threatened species. $<$ www.iucnredlist.org $>$. Downloaded on 07 March 2009.

Lishman, W. A., Teets, T. L., Duff, J. W., Sladen, W. J. L., Shire, G. G., Goolsby, K. M., Bezner Kerr, W. A. and Urbanek, R. P. (1997) A reintroduction technique for migratory birds: leading Canada geese and isolation-reared sandhill cranes with ultralight aircraft. Proc. North Am. Crane Workshop 7: 96-104.

McMillen, J. L. 1988. Productivity and movements of the greater sandhill crane population at Seney National Wildlife Refuge: potential for an introduction of Whooping Cranes. Ph.D. dissertation. Columbus, Ohio: Ohio State University.

Nagendran, M., Urbanek, R. P., and Ellis, D. H. (1996) Special techniques, part D: reintroduction techniques. Pp. 231-240 in D. H. Ellis, G. F. Gee, and C. M. Mirande, eds. Cranes: their biology, husbandry, and conservation. Washington, D.C., and Baraboo, Wisconsin: National Biological Service and International Crane Foundation.

Nesbitt, S. A., Folk, M. J., Spalding, M. G., Schmidt, J. A., Schwikert, S. T., Nicolich, J. M., Wellington, M., Lewis, J. C. and Logan, T. H. (1997) An experimental release of Whooping Cranes in Florida-the first three years. Proc. North Am. Crane Workshop 7: 79-85.

Nesbitt, S. A., Folk, M. J., Sullivan, K. A., Schwikert, S. T. and Spalding, M. G. (2001) An update of the Florida whooping crane release project through June 2000. Proc. North Am. Crane Workshop 8: 62-73.

Toepfer, J. E. and Crete, R. A. (1979) Migration of radio-tagged greater sandhill cranes from Minnesota and Wisconsin. Pp. 159173 in J. C. Lewis, ed. Proceedings of the 1978 crane workshop. Fort Collins, Colorado: Colorado State University Printing Service.

Urbanek, R. P. 1988. Migration of sandhill cranes from the north shore of the north channel of Lake Huron, Ontario. Columbus, Ohio: Ohio Cooperative Fish and Wildlife Research Unit.

Urbanek, R. P. and Bookhout, T. A. (1992) Development of an isolation-rearing/gentle release procedure for reintroducing migratory 
cranes. Proc. North Am. Crane Workshop 6: 120-130.

Urbanek, R. P. and Bookhout, T. A. (1994) Performance of captive-reared cranes released into a migration route in eastern North America. Pp. 121-129 in H. Higuchi and J. Minton, eds. The future of cranes and wetlands. Tokyo: Wild Bird Society of Japan.

Urbanek, R. P., Duff, J. W., Swengel, S. R. and Fondow, L. E. A. (2005a) Reintroduction techniques: post-release performance of sandhill cranes (I) released into wild flocks and (2) led on migration by ultralight aircraft. Proc. North Am. Crane Workshop 9: 203-211.

Urbanek, R. P., Fondow, L. E. A., Satyshur, C. D., Lacy, A. E., Zimorski, S. E., and Wellington, M. (2005b) First cohort of migratory whooping cranes reintroduced to eastern North America: the first year after release. Proc. North Am. Crane Workshop 9: $213-223$.

\section{RICHARD P. URBANEK*}

U.S. Fish and Wildlife Service, Necedah National Wildlife Refuge, W7996 2oth Street West, Necedah, WI 54646, U.S.A.

LARA E. A. FONDOW, SARA E. ZIMORSKI, MARIANNE A. WELLINGTON

International Crane Foundation, E-11376 Shady Lane Road, Baraboo, WI 53913, U.S.A.

MARK A. NIPPER

Operation Migration, 174 Mary Street, Port Perry, ON L9L 1B7, Canada.

${ }^{*}$ Author for correspondence; e-mail: richard_urbanek@fws.gov

Received 20 July 2008; revision accepted 29 April 2009;

Published online 16 October 2009 